\title{
Glibenclamide inhibits cell growth by inducing G0/G1 arrest in the human breast cancer cell line MDA-MB-231
}

Mariel Núñez ${ }^{1}$, Vanina Medina', Graciela Cricco' ${ }^{1}$ Máximo Croci², Claudia Cocca', Elena Rivera', Rosa Bergoc ${ }^{1,3^{*}}$ and Gabriela Martín ${ }^{1}$

\begin{abstract}
Background: Glibenclamide (Gli) binds to the sulphonylurea receptor (SUR) that is a regulatory subunit of ATP-sensitive potassium channels ( $K_{\text {ATP }}$ channels). Binding of Gli to SUR produces the closure of $K_{\text {ATP }}$ channels and the inhibition of their activity. This drug is widely used for treatment of type 2-diabetes and it has been signaled as antiproliferative in several tumor cell lines. In previous experiments we demonstrated the antitumoral effect of Gli in mammary tumors induced in rats. The aim of the present work was to investigate the effect of Gli on MDA-MB-231 breast cancer cell proliferation and to examine the possible pathways involved in this action.

Results: The mRNA expression of the different subunits that compose the $K_{\text {ATP }}$ channels was evaluated in MDA-MB-231 cells by reverse transcriptase-polymerase chain reaction. Results showed the expression of mRNA for both pore-forming isoforms Kir6.1 and Kir6.2 and for the regulatory isoform SUR2B in this cell line. Gli inhibited cell proliferation assessed by a clonogenic method in a dose dependent manner, with an increment in the population doubling time. The $\mathrm{K}_{\text {ATP }}$ channel opener minoxidil increased clonogenic proliferation, effect that was counteracted by Gli. When cell cycle analysis was performed by flow cytometry, Gli induced a significant cell-cycle arrest in G0/G1 phase, together with an up-regulation of p27 levels and a diminution in cyclin E expression, both evaluated by immunoblot. However, neither differentiation evaluated by neutral lipid accumulation nor apoptosis assessed by different methodologies were detected. The cytostatic, non toxic effect on cell proliferation was confirmed by removal of the drug.

Combination treatment of Gli with tamoxifen or doxorubicin showed an increment in the antiproliferative effect only for doxorubicin.
\end{abstract}

Conclusions: Our data clearly demonstrated a cytostatic effect of Gli in MDA-MB-231 cells that may be mediated through $\mathrm{K}_{\text {ATP }}$ channels, associated to the inhibition of the G1-S phase progression. In addition, an interesting observation about the effect of the combination of Gli with doxorubicin leads to future research for a potential novel role for Gli as an adjuvant in breast cancer treatment

Keywords: Glibenclamide, Potassium channels, MDA-MB-231, Cytostatic effect

\footnotetext{
* Correspondence: rmbergoc@gmail.com

${ }^{1}$ Radioisotopes Laboratory, School of Pharmacy and Biochemistry, University of Buenos Aires, Buenos Aires, Argentina

${ }^{3}$ Institute of Health Sciences Barceló, Buenos Aires, Argentina

Full list of author information is available at the end of the article
} 


\section{Background}

Sulphonylureas are used to increase insulin secretion in patient with type 2-diabetes due to their direct action on pancreatic $\beta$ cells. These drugs bind to the $\beta$ cell sulphonylurea receptor (SUR) that is a regulatory subunit of ATP-sensitive potassium channels ( $\mathrm{K}_{\text {ATP }}$ channels) [1-3]. $\mathrm{K}_{\mathrm{ATP}}$ channels regulate the transport of potassium ions through cell membranes. A diverse group of compounds can bind to $\mathrm{K}_{\mathrm{ATP}}$ channels causing them to open or close. The opening of potassium channels in the cell membrane produces a hyperpolarization of membrane potential. These channels are hetero-octameric complexes that consist of two rings: an inner ring of four inwardly rectifying $\mathrm{K}^{+}$channels (Kir6.X) that forms the pore through which potassium ions pass, and an outer ring that comprises four SUR subunits. Two isoforms have been described for Kir6.X (Kir6.1 and Kir6.2) and also for SUR (SUR1 and SUR2; SUR2 also has two splice variants, SUR2A and SUR2B) [4]. In pancreatic $\beta$ cells binding of sulphonylureas to SURs produce the closure of $\mathrm{K}_{\text {ATP }}$ channels reducing cellular potassium efflux thus favoring membrane depolarization, the induction of $\mathrm{Ca}^{2+}$ influx, and insulin secretion [1-3].

Glibenclamide (Gli), a diarylsulphonilurea that blocks specifically $K_{\text {ATP }}$ channels, is widely employed in the treatment of diabetic patients [5], but various reports also described its antiproliferative effect in different neoplastic cell lines [6,7]. Additionally, the inhibition of other classes of potassium channels also leads to a decrease of proliferation in normal and cancer cells $[8,9]$.

Breast cancer is the neoplastic disease most frequently observed in women all over the world [10-12]. A high proportion of mammary tumors are positive for estrogen receptors $\alpha(E R \alpha)$ and consequently antihormonal therapy is indicated. The selective estrogen receptor modulator tamoxifen continues to be the drug regularly used in patients harboring this kind of tumors due to its efficacy and low toxicity [13]. However, approximately 30\% of ER $\alpha(+)$ tumors do not respond to tamoxifen or develop resistance in the course of the treatment. In addition, it is known that approximately $30 \%$ of tumors do not express ER $\alpha$ [14]. Although a large number of drugs have been developed for the treatment of ER $\alpha$ (-) tumors, most of them give rise to important toxic effects. In order to attain better therapeutic effectiveness, combination cytotoxic treatments for aggressive cancers have been employed in clinics. The simultaneous use of drugs with different molecular targets can delay the emergence of chemoresistance whereas when drugs are directed to the same cellular pathway they could work synergically for higher efficacy and selectivity. However, combination therapy may also increase toxicity [15]. Doxorubicin is considered a highly effective agent in the treatment of aggressive breast cancer patients sometimes combined with cyclophosphamide, taxanes and/or 5-fluorouracil; however, resistance to doxorubicin is common $[16,17]$. The search for effective drugs with low side effects is still a challenge to researchers.

MDA-MB-231 cell line derived from a human breast carcinoma that do not express ER $\alpha$, is often used as an experimental non hormone-dependent tumor model $[18,19]$. The objective of the present work was to investigate the effect of Gli on MDA-MB-231 cells proliferation and to examine the possible pathways involved in this action.

\section{Material and methods \\ Materials}

MBA-MB-231 cells were obtained from American Type Culture Collection (ATCC). Gli was kindly provided by Investi-Farma $\mathrm{SA}$, Buenos Aires, Argentina. Tamoxifen (Tam) was a gift from Gador Laboratories SA, Buenos Aires, Argentina. RPMI 1640 medium and fetal bovine serum (FBS) were purchased from GIBCO, Invitrogen, CA, USA. Ribonuclease, propidium iodine, 3,3'dihexyloxacarbocyanine iodide (DiOC6), saponine, FITC-labeled anti-rabbit, 5-bromo- $2^{\prime}$-deoxyuridine (BrdU), mouse anti-BrdU monoclonal antibody, FITC-conjugated anti-mouse IgG, 4',6-Diamidino-2phenyindole, dilactate (DAPI), 5-bromo-4-chloro-3-indolyl- $\beta$-d-galactoside (X-gal), mouse anti- $\beta$-actin polyclonal antibody, $27^{\text {Kip1 }}$ monoclonal antibody and Nile-red stain were purchased from Sigma, St Louis, MO, USA. Apoptag ${ }^{\circledR}$ PLUS Peroxidase In Situ Detection Kit S701 was from Chemicon International, CA, USA. Rabbit polyclonal antibodies against human $\mathrm{Bax}, \mathrm{Bcl}-2$ and $\mathrm{Bcl}-\mathrm{x}_{\mathrm{L} / \mathrm{S}}$ were from Santa Cruz Biotechnologies, Santa Cruz, CA, USA. Mouse anti-cyclin B1 monoclonal antibodies, mouse anti-cyclin E monoclonal antibodies, and rabbit anti-cyclin D1 monoclonal antibodies were from Cell Signaling Technology, Inc., Danvers, MA, USA. Annexin V-FITC was from Biosciences, USA. Chemiluminiscence system (ECL) was from Amersham Biosciences Argentina SS (Argentina). Nitrocellulose membranes were from Santa Cruz Biotechnologies, Santa Cruz, CA, USA. Multiwells were from TPP, Switzerland. All other reagents were of analytical grade.

\section{Methods}

Reverse transcriptase polymerase chain reaction (RT-PCR) analysis

Total cellular RNA was extracted using Trizol ${ }^{\circledR}$ according to the instructions of the manufacturer (GIBCO, Life Technologies, USA). Total RNA $(2 \mu \mathrm{g})$ was added to the reverse transcription (RT) reaction mixture $(20 \mu \mathrm{l})$ in the presence of oligo-dT primers and samples were incubated at $37^{\circ} \mathrm{C}$ for 60 minutes. The quality of each individual's cDNA was confirmed by PCR with primers for $\beta$-actin producing bands of the expected size (data not shown).The primers used were employed previously 
by other workers for Kir6.1, Kir6.2, SUR1 [4], SUR2A and SUR2B [20]. PCR conditions were as follows: Kir6.1 forward (5'-CATCTTTACCATGTCCTTCC-3') and reverse ( $5^{\prime}$-GTGAGCCTGAGCTGTTTTCA-3'), 336 bp; Kir6.2 forward (5'-GCTTTGTGTCCAAGAAAGG1-3') and reverse (5'-CCAAAGCCAATAGTCACTTG-3'), $301 \mathrm{bp} ; 5 \mathrm{~min} 95^{\circ} \mathrm{C}, 35$ cycles of $95^{\circ} \mathrm{C}$ for $20 \mathrm{~s}, 52^{\circ} \mathrm{C}$ for $45 \mathrm{~s}$, and $72^{\circ} \mathrm{C}$ for $1 \mathrm{~min}$. SUR1 forward (5' -CGATGC CATCATCACAGAAG-3') and reverse (5'-CTGAG CAGCTTCTCTGGCTT-3'), 291 bp; SUR2A foward (5'-ATGCGGTTGTCACTGAAGG-3') and reverse (5'AATAGAAGAGACACGGTGAGC-3'), 215 bp; SUR2B forward (5'-GATGCGGTTGTCACTGAAGG-3') and reverse ( $5^{\prime}$-TCATCACAATAACCAGGTCTGC-3'), 244 bp; $5 \mathrm{~min} 95^{\circ} \mathrm{C}, 35$ cycles of $95^{\circ} \mathrm{C}$ for $1 \mathrm{~min}, 55^{\circ} \mathrm{C}$ for $1 \mathrm{~min}$, and $72^{\circ} \mathrm{C}$ for $2 \mathrm{~min}$. Reactions were terminated by final elongation step of $7 \mathrm{~min}$ at $72^{\circ} \mathrm{C}$ (Gene Amp PCR System 2400, PerkinElmer, MA, USA). Negative controls were performed with water instead of cDNA. PCR products were subjected to gel electrophoresis and detected by gel documentation system LumiBis DNR (Bio-Imaging Systems, Jerusalem, Israel).

\section{Cell culture}

MBA-MB-231 cels were cultured in RPMI 1640 medium supplemented with $10 \% \mathrm{FBS}, 0.3 \mathrm{~g} / \mathrm{l} \mathrm{L}$-glutamine and $40 \mathrm{mg} / \mathrm{l}$ gentamicine and in the presence of Gli, Tam or vehicle. Cells were maintained at $37^{\circ} \mathrm{C}$ in a humidified atmosphere containing $5 \% \mathrm{CO}_{2}$.

\section{Cell proliferation assay}

For clonogenic assay, cells were seeded in 6-well plates $\left(1.5 \times 10^{3}\right.$ cells/well $)$ and incubated in the presence or absence of drugs for 10 days. Cells were treated with 10 to $50 \mu \mathrm{M}$ Gli, 0.005 to $5 \mu \mathrm{M}$ minoxidil; 0.1 to $5 \mu \mathrm{M}$ tamoxifen; 0.01 to $0.1 \mathrm{nM}$ doxorubicin or with the concentration of Gli that inhibited the proliferation to the $50 \%$ $\left(\mathrm{IC}_{50}\right)$ plus different doses of minoxidil, tamoxifen or doxorubicin to assess the combined action of both drugs. Cells were then fixed with $10 \%$ formaldehyde in phosphate-buffered saline, PBS, stained with $1 \%$ toluidine blue in $70 \%$ ethanol. The clonogenic proliferation was evaluated by counting the colonies with 50 cells or more. The results are expressed as a percentage of control values.

\section{Determination of doubling time}

For doubling time determination cells were seeded in 6-well plates $\left(4 \times 10^{4}\right.$ cells/well), starved for $24 \mathrm{~h}$ and then incubated with $\mathrm{IC}_{50}$ Gli $(25 \mu \mathrm{M})$ or vehicle for up to $96 \mathrm{~h}$. Cells were trypsinized at $0,1,2,3$ and 4 days and counted using a hemocytometer. All experiments were performed in the logarithmic phase of cell growth. Triplicate plates were analyzed for each treatment and each time. The following formula was used to calculate the doubling time: $\mathrm{N}_{\mathrm{t}}=\mathrm{N}_{0} \times \mathrm{e}^{\mathrm{kxt}}$, where $\mathrm{N}_{0}$ was the initial number of cells that increased exponentially with a rate constant, $k$. The doubling time $(\mathrm{T})$ was calculated as: $T=\ln 2 / k$. The GraphPad Prism 5.0 software (GraphPad Software Inc., Philadelphia, U.S.A.) was employed.

\section{Cell cycle analysis by flow cytometry}

Cells were cultured for $24 \mathrm{~h}$ without FBS. Synchronized cells were then treated with $\mathrm{IC}_{50}$ Gli $(25 \mu \mathrm{M})$ or vehicle immediately after release from the block and harvested for up to $72 \mathrm{~h}$. Then cells were collected by trypsinization, fixed with ice cold methanol, centrifuged and resuspended in $0.5 \mathrm{ml}$ of propidium iodide (PI) staining solution $(50 \mu \mathrm{g} / \mathrm{ml}$ PI in PBS containing $0.2 \mathrm{mg} / \mathrm{ml}$ of DNase-free RNase A). After incubation for $30 \mathrm{~min}$ at $37^{\circ} \mathrm{C}$, samples were evaluated by flow cytometry (Becton Dickinson, USA). Cell cycle distribution was analyzed using Cylchred 1.0.2 software (Cardiff University, UK).

\section{Quantification of DNA synthesis}

The quantification of cellular DNA synthesis was performed on cells by the addition of $30 \mu \mathrm{M}$ BrdU for $2 \mathrm{~h}$. Cells grown on sterile slides were washed with PBS and fixed with $10 \%$ formaldehyde in PBS. To denature the DNA into single-stranded molecules, cells were incubated with $3 \mathrm{~N} \mathrm{HCl}$ for $30 \mathrm{~min}$ at room temperature. Then cells were washed in $1 \mathrm{ml}$ of $0.1 \mathrm{M} \mathrm{Na}_{2} \mathrm{~B}_{4} \mathrm{O}_{7}$, $\mathrm{pH} 8.5$ to neutralize the acid and were then incubated overnight at $4^{\circ} \mathrm{C}$ with mouse anti-BrdU monoclonal antibody (1:50). Then, cells were incubated for $2 \mathrm{~h}$ at $37^{\circ} \mathrm{C}$ with FITC-conjugated anti-mouse IgG (1:100). After washed with PBS, cells were stained with DAPI (1:8000). Fluorescence was further visualized by fluorescence microscope. At least 1000 cells were scored for each determination.

\section{Apoptosis}

Apoptotic MDA-MB-231 cells were detected after treatment with Gli or vehicle for $72 \mathrm{~h}$. Phosphatidylserine exposure on the surface of apoptotic cells was detected by flow cytometry after staining with Annexin V-FITC and PI $(50 \mu \mathrm{g} / \mathrm{ml})$. Data were analyzed using WinMDI 2.8 software (Scripps Institute, CA, USA).

\section{Mitochondrial transmembrane potential}

Variations of the mitochondrial transmembrane potential of the cells, $\Delta \Psi_{\mathrm{m}}$, were studied by means of the uptake of DiOC6, a specific fluorochrome that has been widely used in monitoring $\Delta \Psi_{\mathrm{m}}$. Cells were plated and treated $24 \mathrm{~h}$ after with $25 \mu \mathrm{M}$ Gli for different incubation periods (24, 48 and $72 \mathrm{hs})$. The diluted dye at a final concentration of $40 \mathrm{nM}$ in PBS was applied to cells for 
15 min at $37^{\circ} \mathrm{C}$. Cells were then washed twice with PBS, harvested and then analyzed by flow cytometry (Becton Dickinson, USA). Results were expressed as the percentage of mean fluorescence of respective controls.

\section{Determination of cell cycle and apoptosis related proteins Flow cytometry}

After treatment with Gli or vehicle for 72 h MDA-MB231 cells were harvested, fixed with $4 \%$ formaldehyde and permeabilized with saponine. To evaluate intracellular protein content, cells were incubated with rabbit anti-Bcl-2 and rabbit anti-Bax antibodies. After washing, cells were incubated for $20 \mathrm{~min}$ with FITC-labeled antirabbit. The samples were analyzed with a FACScalibur flow cytometer (Becton Dickinson, USA). Data analysis was performed using WinMDI 2.8 software. For each sample 20,000 events were collected. The results are expressed as the percentage of respective control values.

\section{Western blot assay}

Cells were placed on ice and washed twice with cold PBS. Cells were then scraped into a lysis buffer $(100 \mathrm{mM}$ Tris/ $\mathrm{HCl}$ buffer, $\mathrm{pH} 8$, containing $1 \%$ Triton $\mathrm{X}-100$ and protease inhibitors) and incubated for $15 \mathrm{~min}$ on ice. After centrifugation at $6000 \mathrm{rpm}$ for $10 \mathrm{~min}$, the supernatants were used for protein determination according to Bradford assay [21]. For Western blot, loading buffer (100 mM Tris/HCl buffer, $\mathrm{pH} 8$, containing 1.7\% sodium dodecyl sulfate (SDS), $0.02 \%$ bromophenol blue, $1.5 \%$ dithiotreitol, and $5 \%$ of glycerol) was added to samples and they were boiled for 3 minutes. Equal amounts of proteins $(50 \mu \mathrm{g})$ were fractionated on SDS-polyacrylamide gels (12\%) and transferred electrophoretically onto nitrocellulose membranes. Membranes were blocked and probed overnight with primary mouse anti-cyclin $\mathrm{D}_{1}$ (1:100), mouse anti-cyclin E (1:500), mouse anti-cyclin B (1:200), mouse anti-p27 ${ }^{\text {Kip1 }}$ (1:200), rabbit anti-Bax (1:500), rabbit anti-Bcl- $\mathrm{x}_{\mathrm{L} / \mathrm{S}}(1: 500)$ and mouse anti- $\beta$-actin (1:1000) antibodies. Immunoreactivity was detected by using horseradish peroxidase-conjugated anti-mouse or anti-rabbit IgG, as appropriate, and visualized by enhanced chemiluminescence. Densitometric analyses were performed using the software Image J 1.32 J (NIH, USA).

\section{Evaluation of senescence-like phenotype}

Senescence-associated $\beta$-galactosidase (SA- $\beta$-Gal) activity was detected in cells as previously described by Dimri [22] with some modifications. Cells treated with Gli $(25 \mu \mathrm{M})$ or vehicle for 72 hs were fixed in $3.0 \%$ formaldehyde for $5 \mathrm{~min}$, washed in phosphate buffered solution (PBS) and stained in $1 \mathrm{mg} / \mathrm{ml} \mathrm{X-gal} \mathrm{solution} \mathrm{at} \mathrm{pH} 6.0$ for 4 hs at $37^{\circ} \mathrm{C}$. SA- $\beta$-Gal positive cells were stained in blue. To visualize the cell architecture, the slides were counter-stained by haematoxylin and quantified by optical microscopy. At least 1000 cells were scored for each determination.

\section{Lipid accumulation}

In order to examine the possible action of Gli in lipid accumulation, a classic terminal differentiation marker in mammary cells, the levels of neutral lipid were measured by flow cytometry using Nile-red staining [23]. Cells treated with Gli or vehicle for 2, 3 or 7 days were fixed and then incubated with Nile-red at a final concentration of $1 \mu \mathrm{g} / \mathrm{ml}$ in PBS for $20 \mathrm{~min}$ at room temperature. Cells were then analyzed by flow cytometry (Becton Dickinson, USA).

Data analysis was performed using WinMDI 2.8 software (Scripps Institute, CA, USA). The results were expressed as a percentage of control values.

\section{Cytostatic effect of glibenclamide}

MDA-MB-231 cells $\left(1 \times 10^{4}\right.$ cells/well) were plated into 6-well plates. After $24 \mathrm{~h}$, cells were treated with $25 \mu \mathrm{M}$ Gli or vehicle and detached with trypsin 3 or 7 days later. Cells were then counted and seeded in 6-well plates $\left(1.2 \times 10^{3}\right.$ cells/well) in triplicates. After 10 days in culture, colonies were fixed with $10 \%$ buffered formalin and stained with $1 \%$ toluidine blue in $70 \%$ ethanol. The number of colonies was determined and normalized to the number of colonies in controls.

\section{Statistical analysis}

In all cases the data shown are the means \pm SEM of at least three independent experiments. Statistical analysis is indicated in each legend. Data were analyzed using the GraphPad Prism 5.0 (GraphPad Software Inc., Philadelphia, U.S.A.) and P values less than 0.05 were considered statistically significant.

\section{Results}

\section{Expression of $\mathrm{K}_{\text {ATP }}$ channels in MDA-MB-231 cells}

Though many reports describe the presence of different potassium channels in diverse human cancer cell lines, at present there is little evidence about the expression of $\mathrm{K}_{\text {ATP }}$ channels in breast cancer cells. Since Gli is a specific blocker of $\mathrm{K}_{\mathrm{ATP}}$ channels, the expression of mRNA for different subunits (Kir6.1, Kir6.2 and SURs) was examined by RT-PCR in MDA-MB-231 cells. As shown in Figure 1A bands of 336 and 301 bp for Kir6.1 and Kir6.2 respectively were detected after electrophoresis, indicating gene expression of pore components for at least two channel types in this cell line. Furthermore, a predicted band of $244 \mathrm{bp}$ was found indicating the expression of SUR2B gene. The expression of SUR1 and SUR2A genes was not detected (291 bp and $215 \mathrm{bp}$, respectively). Altogether these results indicate that poreforming and regulatory subunits are expressed in this 

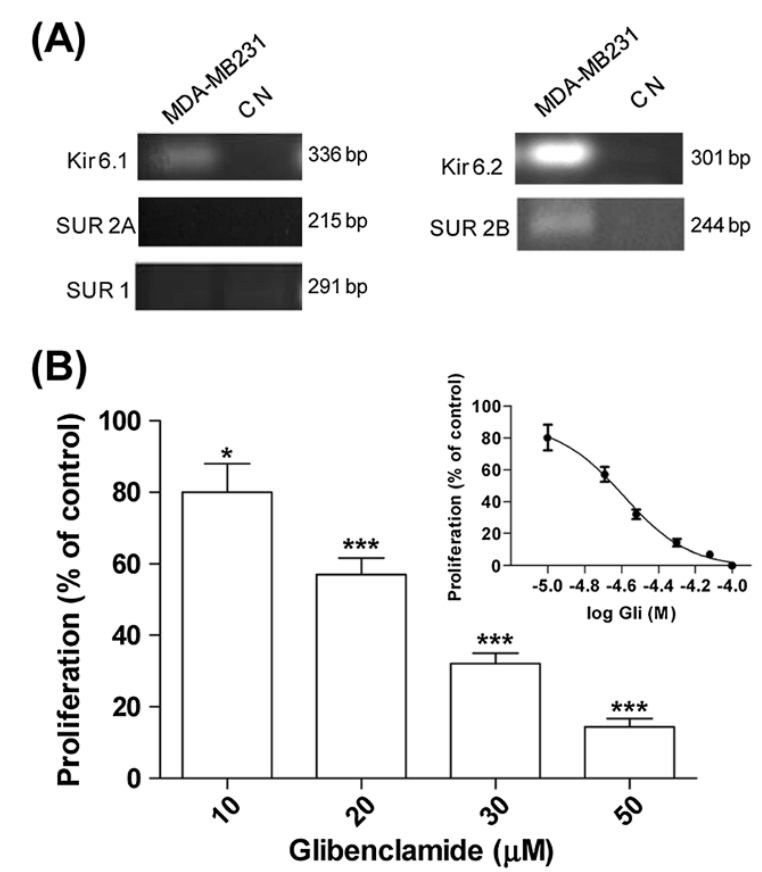

(C)

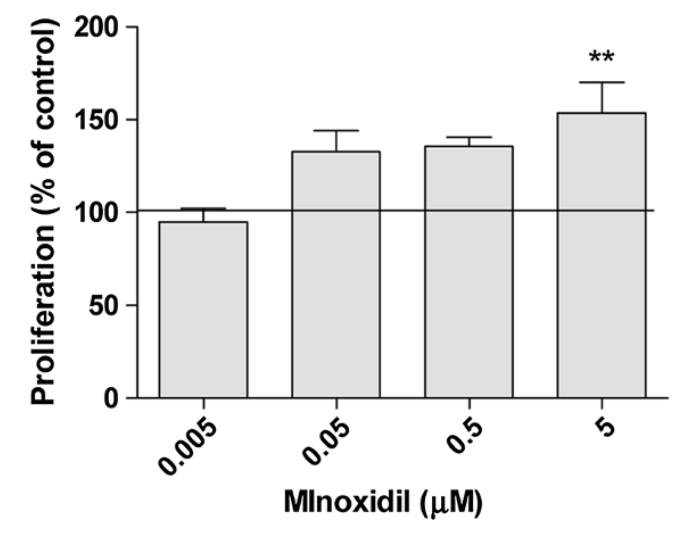

(D)

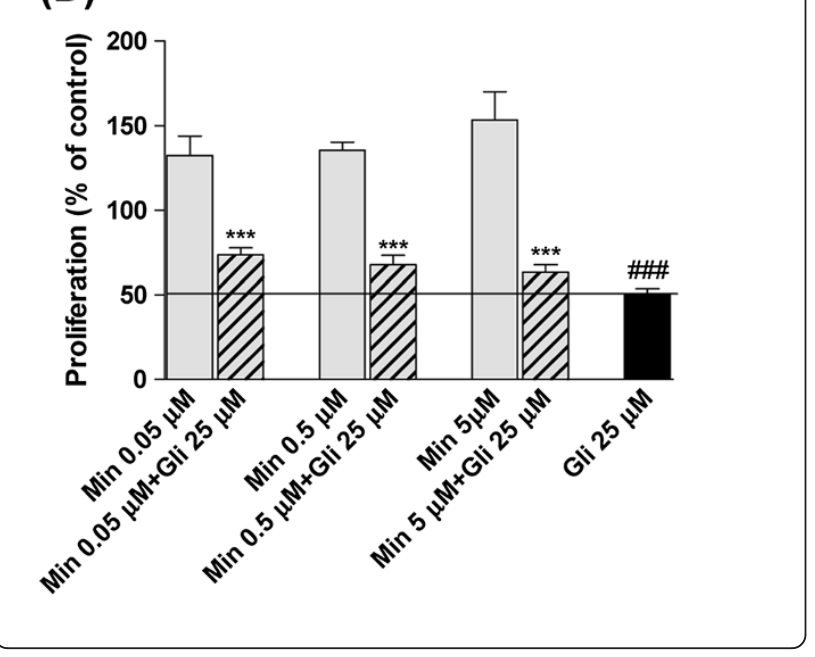

Figure 1 Effect of Glibenclamide, a specific blocker of the $\mathrm{K}_{\text {ATP }}$ channels, on cell growth. The figure shows the mRNA expression of $K_{\text {ATP }}$ channels components and the effect of Gli and minoxidil (Min) on cell proliferation in MDA-MB-231 cells. Proliferation was evaluated by counting of colonies with 50 cells or more and expressed as percentage of values obtained with vehicle (means \pm SEM of three experiments on parallel). Panel $\mathbf{A}$ : mRNA expression of $\mathrm{K}_{\text {ATP }}$ channels in MDA-MB-231 cells by RT-PCR analysis. Agarose gel electrophoresis of PCR products showed bands corresponding to: Kir6.1 (336 bp), Kir6.2 (301 bp), SUR2B (312 bp). No bands were detected for SUR2A (215 bp) or SUR1 (291 bp). CN: negative control Panel B: Inhibition of proliferation obtained with different concentrations of Gli $(10,20,30$ or $50 \mu \mathrm{M})$. Insert shows the doseresponse curve used to determine $I C_{50}\left(I C_{50}=25 \mu M\right)$. Panel $\mathbf{C}$ : Increase of proliferation obtained with Min $0.05 ; 0.5$ or $5 \mu \mathrm{M}$. Panel D: Results obtained with $I C_{50}$ Gli plus different concentration of Min. Panel B and C: ${ }^{*} p<0.05$ vs. control; ${ }^{* *} p<0.01$ vs control; ${ }^{* *} p<$ 0.001 vs. control, One way ANOVA and Dunnet post test. Panel $\mathbf{D}$ : ${ }^{* * *} \mathrm{p}<0.01$ vs. Min $0.05 \mu \mathrm{M}$; vs. Min $0.5 \mu \mathrm{M}$; vs. Min $5 \mu$ M. ${ }^{\# \# \#} \mathrm{p}<$ 0.001 vs. Min $0.05 \mu \mathrm{M}$; vs. Min $0.5 \mu \mathrm{M}$; vs. Min $5 \mu \mathrm{M}$. One way ANOVA and Tuckey post test.

cell line. ER $\alpha(+)$ MCF-7 breast cancer cells were also analyzed and Kir6.1, Kir6.2 and SUR1 were found expressed in this cell line (data not shown).

\section{Effect of glibenclamide on cell proliferation}

The effect of Gli on cell proliferation was tested by means of a clonogenic assay. A significant concentration dependent inhibition on cell growth was observed when Gli was added to cell cultures in concentrations over 10 $\mu \mathrm{M}$; the $\mathrm{IC}_{50}$ value was $25.6 \pm 3.2 \mu \mathrm{M}$ (Figure $1 \mathrm{~B}$ ). The increased doubling time ( $\mathrm{T}$ value, Table 1 ) obtained in the presence of $25 \mu \mathrm{M}$ Gli is in concordance with the inhibition of proliferation previously demonstrated using the clonogenic assay.

In order to support the hypothesis of $\mathrm{K}_{\mathrm{ATP}}$ channels involvement in MDA-MB-231 cell proliferation we used minoxidil, a well known specific opener of these channels. The results showed an increase in cell clonogenic growth for concentrations over $0.05 \mu \mathrm{M}$, which became significant at $5 \mu \mathrm{M}$ (Figure 1C). Figure 1D shows that the increment in proliferation produced by the channel opener was totally reversed by $25 \mu \mathrm{M}$ Gli.

The analysis of cell cycle phase distribution demonstrated that Gli produces a significant increase in the number of cells in G1 phase at 24, 48 and $72 \mathrm{~h}$ post treatment, clearly demonstrating a significant G0/G1 cell cycle arrest (Figure 2A). A consequent decrease in cells

Table 1 Determination of cell doubling time

\begin{tabular}{ll}
\hline Treatment & Duplication Time (hs) \\
\hline Control & $24.0 \pm 4.3$ \\
Gli & $34.6 \pm 4.5 *$ \\
\hline
\end{tabular}

Gli: $25 \mu \mathrm{M}$ gliblenclamide. * $\mathrm{p}<0.05$ vs control, $t$ test. 

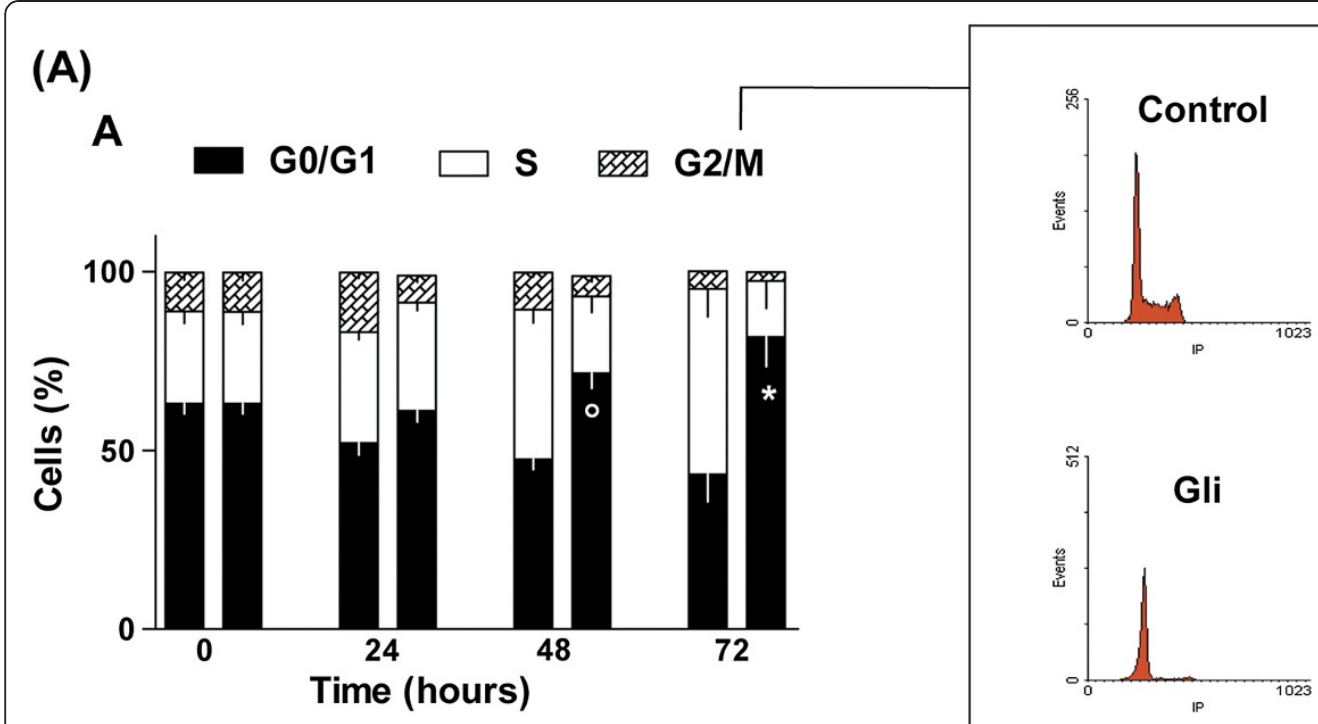

(B)
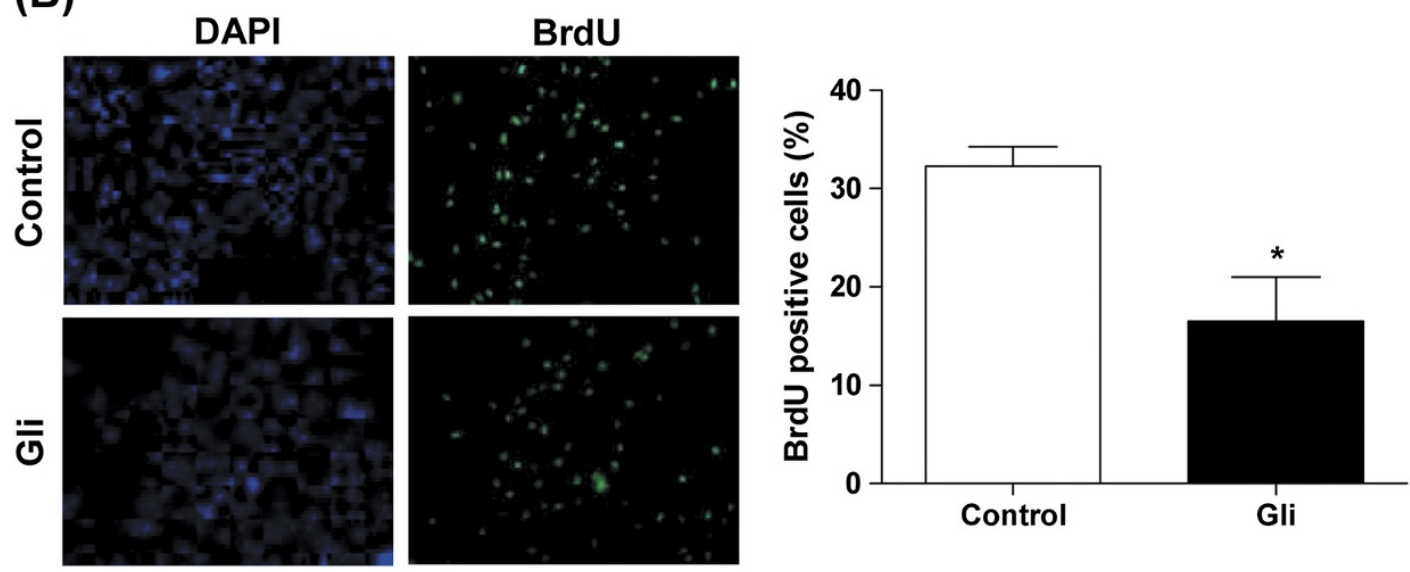

(C)

Control Gli

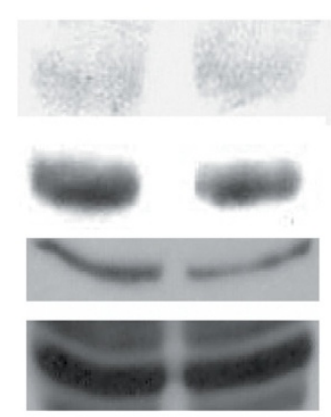

Cyclin D1

$\beta$ - actin

Cyclin E

$\beta$ - actin

\section{Control Gli}

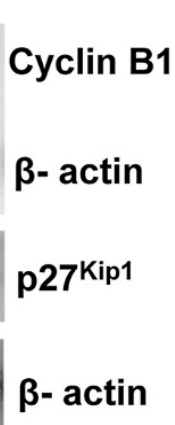

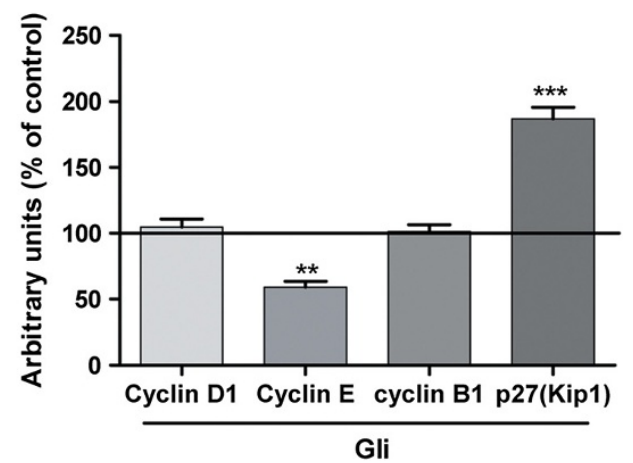

Figure $\mathbf{2}$ (See legend on next page.) 
(See figure on previous page.)

Figure 2 Effect of Glibenclamide on cell cycle progression. Panel A: Synchronized MDA-MB-231 cells were treated with $I C_{50} G l i(25 \mu M)$ or vehicle for 24,48 or $72 \mathrm{~h}$ and the fraction of cells in each phase of cell cycle was evaluated by flow citometry. Gli treatment clearly arrested cells at G0/G1 phase. Results are expressed as percentage of the value obtained with vehicle (means \pm SEM of three experiments on parallel). ${ }^{\circ} p<0.01$ vs control; ${ }^{*} \mathrm{p}<0.001$ vs control, $t$ test. Left bars: control; right bars: Gli-treated cells. Panel B: A decrease in BrdU incorporation to DNA was observed when cells were treated with $25 \mu \mathrm{M}$ Gli for $48 \mathrm{~h}$. Results are expressed as the means \pm SEM of three experiments on parallel. ${ }^{*} \mathrm{p}<0.05$ vs. control, $t$ test. Panel C: Expression of G1-S regulatory proteins in MDA-MB-231 cells treated with Gli or vehicle for $72 \mathrm{~h}$ was analyzed by Western blot. Gli decreased the level of cyclin E and increased p2 $7^{\text {Kip1 }}$. Representative immunoblot images of cyclins D1, B1, E and p2 $7^{\text {Kip } 1}$ are illustrated. Relative quantification was performed by densitometric analyses. Actin densitometric values were used to standardize for protein loading. Bars represent the mean \pm SEM of three independent experiments. ${ }^{* *} \mathrm{p}<0.01$ vs control; ${ }^{* * *} \mathrm{p}<0.001$ vs control, $t$ test.

in S and G2 phase versus control was also observed. Consistent with these observations, Gli inhibited the active DNA synthesis when it was evaluated by BrdU incorporation (Figure 2B).

The expression of proteins implicated in the control of different phases of the cell cycle was investigated by Western blot analysis. Studies of proteins specifically related with phase G1 of cell cycle demonstrated that 25 $\mu \mathrm{M}$ Gli reduced expression of cyclin $\mathrm{E}$ whereas cyclin D1 remained unchanged after $72 \mathrm{~h}$ of treatment. Furthermore, p2 $7^{\text {Kip } 1}$ levels were up-regulated in the same experimental conditions. In addition, the level of cyclin $\mathrm{B} 1$ expression, which is involved in the control of G2-M transition, was not modified by Gli treatment.

\section{Effect of glibenclamide on cell death}

To determine if the decrease in proliferation exerted by Gli could be due to an apoptotic effect, we assessed apoptosis by two different methodologies. Results showed that Gli did not increase the number of apoptotic cells by Annexin-V staining ( $3.66 \pm 0.62 \%$ in control vs $3.70 \pm 0.69 \%$ ) after $72 \mathrm{~h}$ of treatment (Figure 3). In accordance, neither it produced the disruption of the mitochondrial transmembrane potential $\left(\Delta \Psi_{\mathrm{m}}\right)$ that is associated with mitochondrial dysfunction and linked to cell death and loss of cell viability (Table 2).

It is known that the Bcl-2 family of mitochondrial proteins is strongly linked to the process of apoptotic cell death; some members of the family act as antiapoptotic proteins such as $\mathrm{Bcl}-2, \mathrm{Bcl}-\mathrm{x}_{\mathrm{L}}$, while others act as inductors of cell death as Bcl- $x_{S}$ and $\mathrm{Bax}$ [24-26]. We determined the expression of these proteins by flow cytometry and Western blot. By both methodologies we showed that $72 \mathrm{~h}$ after treatment with $25 \mu \mathrm{M}$ Gli, the level of expression of proapoptotic protein Bax was slightly increased in relation to control at the same time, although this increase was not statistically significant (Figure 4A and $4 \mathrm{~B}$ ). On the other hand, antiapoptotic $\mathrm{Bcl}-2$ protein did not modify its expression when cells were treated with Gli (Figure 4B). The pro-apoptotic isoform, $\mathrm{Bcl}-\mathrm{x}_{\mathrm{S}}$, showed a very low expression while the antiapoptotic isoform $\mathrm{Bcl}-\mathrm{x}_{\mathrm{L}}$ expression levels were higher but did not significantly change with Gli-treatment (Figure 4A).

We also evaluated the induction of cell senescence as a mechanism of cell death. To identify the senescent cells, senescence-associated $\beta$-galactosidase (SA- $\beta$-GAL)

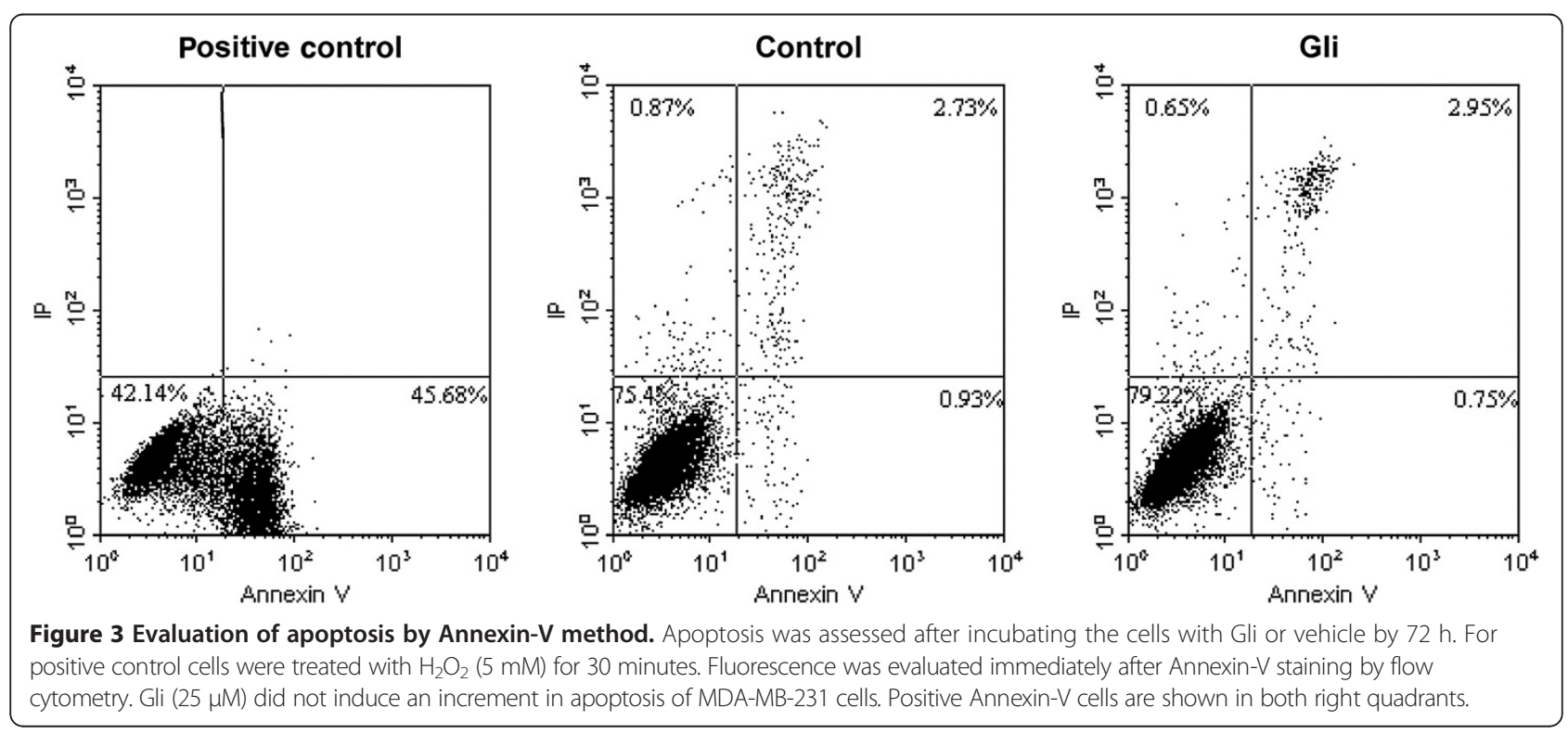


Table 2 Effect of Gli on mitochondrial transmembrane potential $\left(\Delta \Psi_{\mathrm{m}}\right)$

\begin{tabular}{ll}
\hline Time (hs) & $\Delta \Psi_{\mathrm{m}}(\%$ of control) \\
\hline 24 & $99.7 \pm 7.3$ \\
48 & $97.0 \pm 3.9$ \\
72 & $94.3 \pm 12.7$ \\
\hline
\end{tabular}

Gli: $25 \mu \mathrm{M}$ glibenclamide. p:NS vs. control, One way ANOVA.

activity was assessed. MDA-MB-231 cells treated with $25 \mu \mathrm{M}$ Gli showed an increase in the percentage of senescent cells versus those treated with vehicle $(3.5 \pm 0.4 \%$ vs $1.2 \pm 0.2 \%$; Figure 5 ).

\section{Effect of glibenclamide on cell differentiation}

Differentiation is one possible mechanism involved in the loss of cell proliferative ability. In mammary cells the accumulation of neutral lipids in cytoplasm is a specific marker of this process. We evaluated by flow cytometry the content of neutral lipids using Nile-red staining and results demonstrated no differences between control and $25 \mu \mathrm{M}$ Gli treated cells up to 7 days (Table 3). Sodium butyrate, an effective differentiation agent in $\operatorname{ER} \alpha(+)$ and $\operatorname{ER} \alpha(-)$ breast cancer cells [27], was used as positive control.

\section{Cytostatic effect of glibenclamide}

To determine whether the growth inhibitory effect was reversible, a characteristic of cytostatic agents, cells were treated with $25 \mu \mathrm{M}$ Gli or vehicle for 3 or 7 days and then they were trypsinized and re-plated at low density in the absence of any treatment to assess clonogenic proliferation. Results in Figure 6 showed that there is no significant difference between Gli-pretreated cells for different time periods and control cells, suggesting that the antiproliferative effect of Gli is elicited only when the drug is present and it does not involve cell toxicity.

\section{Combination treatments}

We assayed the combination of Gli with tamoxifen or doxorubicin to explore a possible increase in efficacy. The growth of MDA-MB-231 cells was inhibited by tamoxifen with an $\mathrm{IC}_{50}$ equal to $5 \mu \mathrm{M}$ (Figure 7A). The concentration of Gli that inhibited cell growth in a $50 \%(25 \mu \mathrm{M})$ was used to evaluate the combined action of Gli plus tamoxifen. The inhibitory effect exerted by the combination of Gli plus tamoxifen was similar to that observed for Gli alone (Figure 7B).

Doxorubicin also inhibited cell proliferation in a concentration dependent manner (Figure 7C). The combination of $25 \mu \mathrm{M}$ Gli plus doxorubicin in doses over $0.05 \mathrm{nM}$ was more effective to inhibit cell proliferation than single treatments (Figure 7D).

\section{Discussion}

Different subtypes of potassium channels have been shown to be directly implicated in normal and malignant cell proliferation [9]. Some of these channels are overexpressed in tumors and therefore they are potential targets for anticancer therapies [28].

We have previously demonstrated that Gli exerts an antitumoral action on NMU-induced mammary tumors in rats, which is an experimental model similar in ER expression and hormone-dependence to human breast cancer $[29,30]$. In these tumors Gli action was potentiated by the combination with tamoxifen [31]. In this paper we analyzed the effect of Gli in MDA-MB-231 $E R \alpha(-)$ breast cancer cell proliferation.

We studied the expression of mRNA for the different subunits that constitute $\mathrm{K}_{\mathrm{ATP}}$ channels in MDA-MB-231 cells and determined that these cells express both pore forming subunits, Kir6.1 and Kir6.2, and the regulatory subunit SUR2B. Coincidently, Bondestine et al. have recently reported the expression of SUR2 protein in MDA-MB-231cells, while SUR1 could not be detected in this cell line [32]. In consequence two whole octameric functional channels could be present in MDA-MB-231 cells. In specific tissues different subunit combinations have been detected, e.g., pancreatic $\beta$ cells and neurons have Kir6.2/SUR1 channels, whereas skeletal muscle expresses Kir6.2/SUR2A channels. These differences imply that drugs may have distinct abilities to affect $K_{A T P}$ channels in diverse tissues depending on the type of SUR expressed [20]. Gli binds to every type of SUR and therefore inhibits the activity of all known $K_{\text {ATP }}$ channels [33]. When we assayed the effect of Gli on MDA-MB-231 cell proliferation, results showed that Gli inhibits clonogenic ability in a concentration-dependent way, with an increment in population doubling time. It has been reported that the potassium-dependent changes in membrane potential play a crucial role in the proliferation of many types of normal and tumor cells. The opening of potassium channels in the cell membrane produces a hyperpolarization of membrane potential which is required for the progression through the cell cycle. As a consequence in the presence of potassium channel blockers cell proliferation is inhibited $[34,35]$. Woodfort et al. early determined that different potassium channel antagonists, as Gli, produce a concentration-dependent growth inhibition on MCF-7 cells with a significant arrest of cells in G0/G1 phase [36]. Diverse drugs signaled as specific $K_{\text {ATP }}$ channel openers which include minoxidil, pinacidil and diaxozide augment DNA synthesis and proliferation of normal and tumor cells [37-39]. In the experiments using minoxidil 


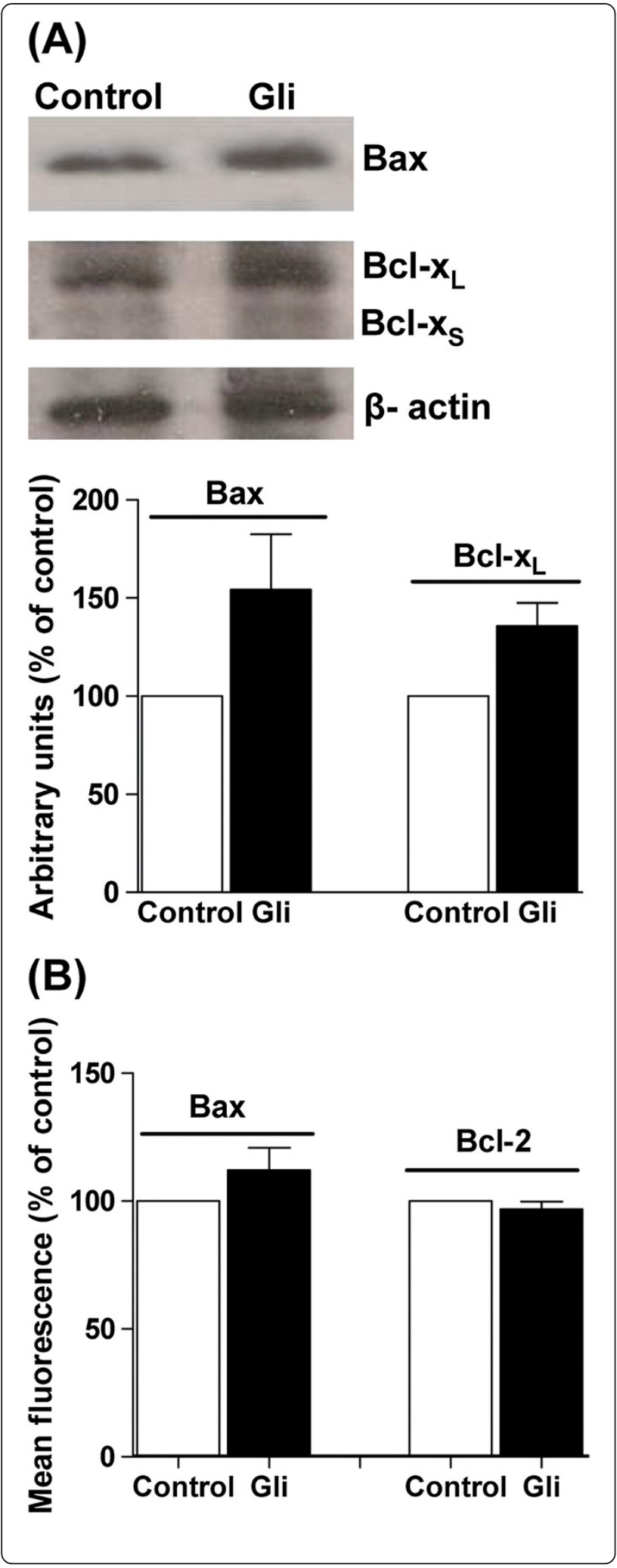

Figure 4 Expression of proteins involved in apoptosis. Panel $\mathbf{A}$ : $\mathrm{Bax}$ and $\mathrm{BCl}-\mathrm{X}_{\mathrm{L} / \mathrm{S}}$ expression determined by Western Blot employing specific antibodies in MDA-MB-231 cells treated for $72 \mathrm{~h}$ with $25 \mu \mathrm{M}$ Gli (Gli) or vehicle (control) cells. The figure shows a representative Western blot of three independent experiments and the quantification of bands obtained for Bax and BCl- $\mathrm{X}_{\mathrm{L} / \mathrm{S}}$ protein. Bars represent the mean \pm SEM of three independent experiments. $p$ : Non significant (NS), $t$ test. Panel B: Expression of $\mathrm{BCl}-2$ and Bax protein in MDA-MB-231 cells treated by $72 \mathrm{~h}$ with $25 \mu \mathrm{M}$ Gli (Gli) or vehicle, obtained by flow cytometry. Bars represent the mean fluorescence \pm SEM obtained by three independent experiments. $\mathrm{p}: \mathrm{NS}, t$ test.

we demonstrated an increase in MDA-MB-231 cell proliferation in concentrations over $0.05 \mu \mathrm{M}$. In addition when different concentrations of minoxidil were combined with $25 \mu \mathrm{M}$ Gli the increment in proliferation was totally reverted. Taken together, these results suggest that Gli could reduce cell proliferation in MDA-MB-231 cells acting through $\mathrm{K}_{\mathrm{ATP}}$ channels.

The analysis of cell cycle progression indicated that $25 \mu \mathrm{M}$ Gli produces an arrest in the G0/G1 phase of cell cycle after $48 \mathrm{~h}$ of treatment. After release of serum starvation, the diminution of the proportion of cells in $\mathrm{S}$ phase in Gli treated cultures was confirmed by the decrease in BrdU incorporation. The cell division cycle integrates several processes and signal transduction pathways to commit the progression of a cell through or its arrest in a specific cell cycle phase. It is generally accepted that the cell cycle regulators cyclin D1 and cyclin E play an important role in early G1 and late G1 progression. In addition, the progression is tightly regulated by the respective cyclin activated subunits cyclin-dependent kinases (Cdks) and their inhibitors (Cdkis). p27 is a member of the Kip/CIP family of Cdkis known to act in the G1 phase of the cell cycle, preventing G1-S transition $[40,41]$. The study of proteins involved in the progression through the phases of cell cycle by immunoblot, has evidenced a decrease in cyclin $\mathrm{E}$ expression with a raise in cyclin inhibitor $\mathrm{p} 27^{\mathrm{Kip} 1}$ in Gli treated MDAMB-231 cells. It is known that the activity of cyclin E in conjunction with its kinase subunit $\mathrm{Cdk} 2$, is limiting for the passage of cells through the restriction point needed for the progression of cells from G1 into S-phase [42]. p2 $7^{\text {Kip } 1}$ binds to the cyclinE/Cdk2 complex and inhibits the kinase thus impeding G1-S passage [43]. Altogether our results suggest that Gli inhibits MDA-MB-231 cell proliferation by hindering G1-S transition. Other authors have also reported that different potassium channels blockers and other agents that cause cell membrane depolarization, produce the arrest of cells in G1 phase with the involvement of different cyclins and inhibitors depending on the cell type [34]. Eto reported that various anticancer agents specifically up-regulate $\mathrm{p} 27^{\text {Kip } 1}$ expression without affecting expression of the other regulatory proteins of G1-S cell cycle transition in human breast cancer 


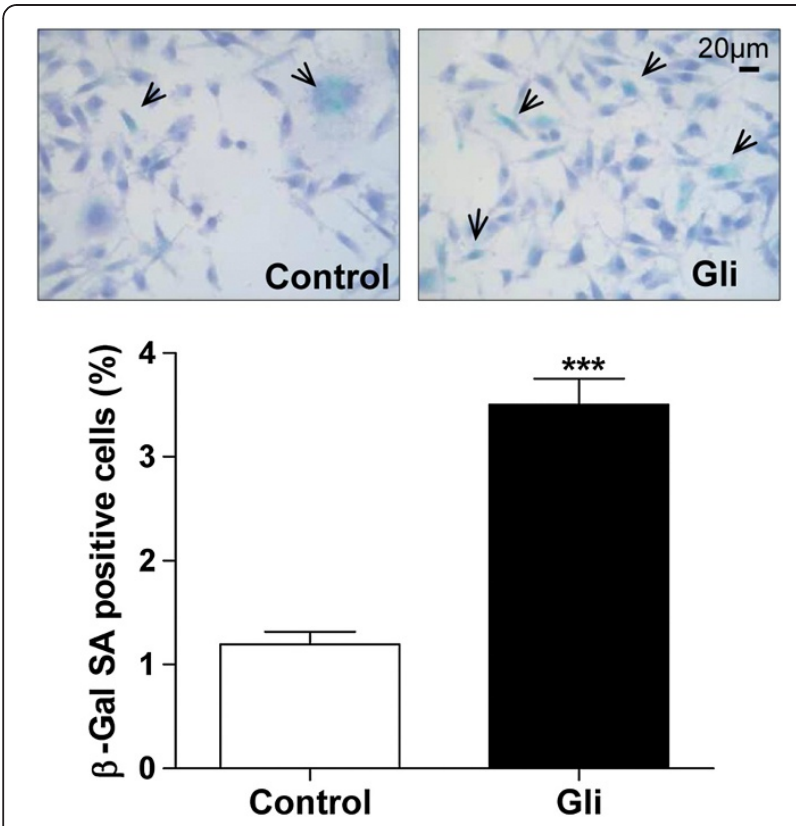

Figure 5 Evaluation of Senescence. MDA-MB-231 cells were cultured for 48 h with $25 \mu \mathrm{M}$ Gli or with vehicle. Senescence was assessed by the activity of SA- $\beta-G A L$. Panel $\mathbf{A}$ : representative photographs where positive SA- $\beta-G A L$ cells are indicated by arrows. Gli produces an increment in cell senescence. Panel B: Percentage of cells SA- $\beta-G A L$ positive were calculated by counting of at least 1000 cells (630X). Bars represent the mean \pm SEM of three independent experiments. ${ }^{*} p<0.001$ vs. control, $t$ test.

cell lines. Moreover, in concordance with our work, he reported that the up-regulation of $\mathrm{p} 27^{\mathrm{Kip} 1}$ expression in these cell lines by anti-cancer agents linearly and positively correlates with the degree of growth inhibition of NMUinduced mammary tumors by the same anti-cancer agent [44].

It has been suggested that chemotherapeutic agents can prevent mammary carcinogenesis and tumor growth through different mechanisms that include apoptosis, differentiation and senescence. Regardless of the mechanism, the evaluation of new antitumoral drugs has as a goal to stop the cell proliferation and produce the death of the tumor cell by apoptotic or non-apoptotic means [45]. Previously, working with NMU-induced mammary

Table 3 Effect of Gli on neutral lipid accumulation

\begin{tabular}{lll}
\hline Time (days) & \multicolumn{2}{l}{ Mean Fluorescence of Nile Red (\% of control) } \\
\hline & Gli & Na Butyrate \\
2 & $92.3 \pm 4.7$ & $134.3 \pm 6.7 * *$ \\
3 & $99.3 \pm 1.7$ & $165.7 \pm 7.3 * * *$ \\
7 & $99.0 \pm 10.1$ & $192.7 \pm 5.3 * * *$ \\
\hline
\end{tabular}

Gli: $25 \mu \mathrm{M}$ glibenclamide. Na Butyrate: $10 \mathrm{mM}$ Sodium butyrate as the positive control. p: NS Gli vs control; ${ }^{* * *} \mathrm{p}<0.001$ butyrate vs control, One way ANOVA and Dunnet test.

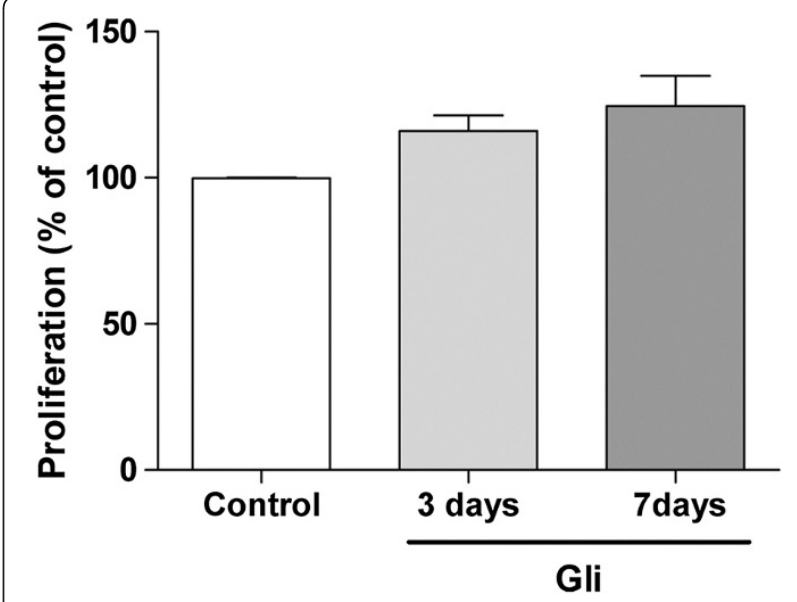

Figure 6 Evaluation of cytotoxic or cytostatic effect. MDA-MB-231 cells treated with $25 \mu \mathrm{M}$ Gli or vehicle for 3 or 7 days were re-seeded at low density to evaluate clonogenic capacity. After 10 days in culture, the number of colonies was determined and normalized to the number of colonies in controls. Bars show that Gli pre-treatment did not signifcantly affect clonogenic capacity. p: NS, One way ANOVA.

tumors in rats, we reported that Gli clearly produced the inhibition of tumor growth through a decrease in cell proliferation and an increase in cell apoptosis and differentiation [31]. It has been reported that Gli produces apoptosis in malignant cell lines such as hepatoblastoma and gastric cancer cells [6,7]. Furthermore, Iwakura and coworkers found that Gli produces a sustained increase in the entrance of $\mathrm{Ca}^{2+}$ to the cells inducing their death through apoptosis [46]. On the contrary, we demonstrated that Gli neither produced apoptosis nor triggered the early events of this mechanism of cell death in MDA-MB-231 cells. We also studied the expression of apoptosis related proteins and determined that Gli did not significantly affect the ratio of the expression of Bax/Bcl-2 proteins at any time evaluated. The relation between antiapoptotic and apoptotic proteins of Bcl-2 family is a better determinant of the susceptibility to apoptosis than the expression of each member separately.

In view that some chemotherapeutic agents are able to produce cell senescence as part of their mechanism of action [45], this possible way of action was studied in the MDA-MB-231 cells treated with Gli. Data obtained in our experiments indicate that there is a slight increase in cell senescence after Gli treatment. However, Gli did not result cytotoxic for neoplastic MDA-MB-231 cells so they clearly keep their clonogenic capacity after being exposed to Gli for seven days. Our results are in agreement with the reported by Woodfork et al., showing that Gli induced a cell cycle arrest in G0/G1 phase in MCF-7 cells that could be reverted by the removal of the drug [36].

Mammary tumor cell differentiation is characterized by an arrest in cell proliferation, nuclear and cytoplasmatic 


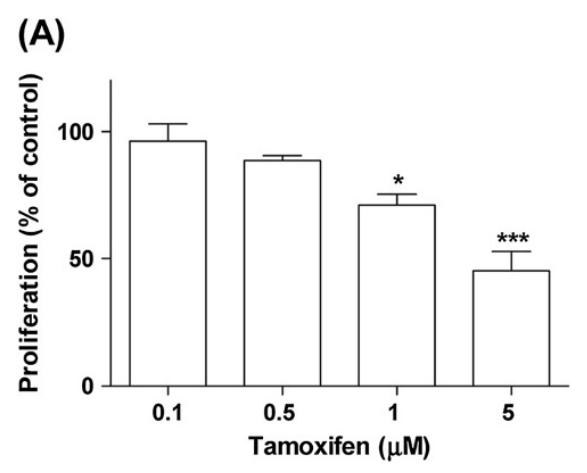

(B)

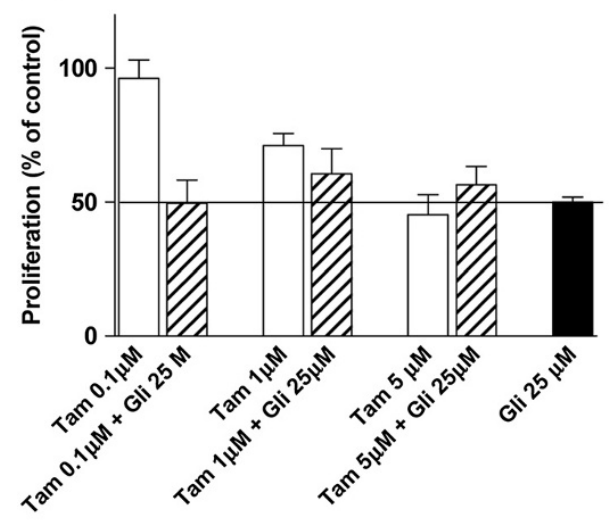

(C)

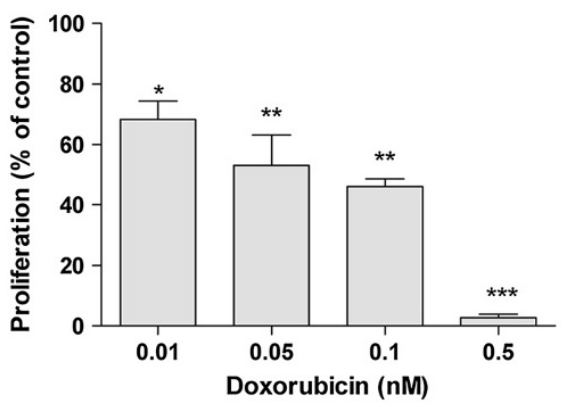

(D)

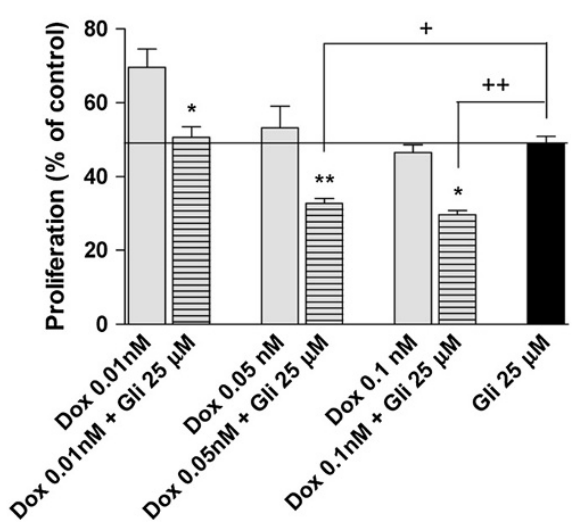

Figure 7 Glibenclamide combination with antineoplasic drugs. MDA-MB-231 cell proliferation was evaluated by counting of colonies with 50 cells or more and expressed as percentage of controls (means \pm SEM of three independent experiments). Panel $\mathbf{A}$ : Results obtained with tamoxifen (Tam) 0.1, 0.5, 1 or $5 \mu \mathrm{M}$. Panel C: Inhibition of proliferation obtained with doxorubicin (Dox) 0.01, 0.05, 0.1 or $0.5 \mathrm{nM}$. Panel $\mathbf{B}$ and $\mathbf{D}$ Results obtained for combination of $25 \mu \mathrm{M}$ Gli plus different concentrations of Tam or Dox. Panel $\mathbf{A}$ and $\mathbf{C}$ : ${ }^{*} p<0.05$ vs. control; ${ }^{* *} p<0.01$ vs. control; ${ }^{* * *} p<0.001$ vs. control, ANOVA and Dunnet post test. Panel B: p: NS vs. Gli $25 \mu \mathrm{M}, t$ test. Panel D: ${ }^{*} p<0.05$ vs. Dox 0.01 nM, vs. Dox 0.1 nM; ** $p<0.001$ vs Dox 0.05 nM; ${ }^{+} p<0.05$ vs. Dox 0.05 nM + Gli $25 \mu \mathrm{M} ;{ }^{++} p<0.001$ vs. Dox 0.1 nM + Gli $25 \mu \mathrm{M}$. One way ANOVA and Tuckey post test.

morphological changes and also by the increased expression of the components of milk such as lipids [47,48]. The accumulation of neutral lipid drops in the cell cytoplasm is used as a marker of this process. In our research Gli did not induce differentiation in MDA-MB-231 cells after treatment for seven days.

Antiestrogens such as tamoxifen are widely used for the treatment of ER $\alpha(+)$ breast cancer. Nevertheless, tamoxifen may elicit pro-apoptotic effects in ER $\alpha(-)$ breast cancer cells by the modulation of various cell signaling pathways in an ER-independent manner [49-53]. However, these effects have generally been reported when relatively high concentrations of tamoxifen were used. In the present work we used tamoxifen in combination with Gli as a strategy to enhance its action in ER $\alpha(-)$ breast cancer even if Gli acts as cytostatic in MDA-MB-231 cells. In our experiments tamoxifen inhibited proliferation significantly at quite high concentrations $(5 \mu \mathrm{M})$ as expected and the combination treatment did not produce a higher inhibitory effect on cell proliferation than each treatment alone. Abdul et al. demonstrated that two nonspecific potassium channels blockers, amiodarone and dequalinium, potentiated the growth inhibitory effects of tamoxifen on human breast, prostate and colon cancer cell lines [38]. In view of our previous results in NMU-induced mammary tumors [31] it could be suggested that Gli may potentiate tamoxifen action only in breast hormonedependent cells.

Doxorubicin is extensively used in chemotherapy for patients with metastatic breast cancer. In spite of its excellent anti-tumor activity, the associated acute and chronic toxicities lead to a relatively low therapeutic index [54]. Therefore, combination treatment with a non-toxic drug which can lower the dose would be advantageous. Our results indicate that the combined treatment of Gli and doxorubicin displayed an additive anti-proliferative effect. In this regard, Gli was found to inhibit multidrug resistance protein (MRP1) activity in human lung cancer cells [55]. In addition it has been also demonstrated that the overexpression of the inwardly rectifying $\mathrm{K}$ channel Kir2.2 decreased doxorubicininduced reactive oxygen species accumulation and cell 
growth inhibition in several cancer cell lines [56]. Further studies are to needed to fully investigate the mechanism involved in the antiproliferative response of MDA-MB-231 cells to the combined treatment glibenclamide with doxorubicin.

\section{Conclusions}

Gli, a drug widely used in clinics for the treatment of type 2-diabetes, is atoxic at doses routinely employed and of low cost. Our experimental data clearly demonstrated that it produces a cytostatic effect in MDA-MB-231 cells inhibiting the G1-S phase progression without inducing cell death or differentiation. Nevertheless, in spite of the lack of cytotoxic action, the interesting observation about the effect of the combination of Gli with doxorubicin on proliferation warrants an exhaustive research to elucidate the pathways involved in this interaction, leading to the consideration of a novel role for Gli as an adjuvant in breast cancer treatment.

\section{Competing interests}

The authors declare that they have no competing interests.

\section{Authors' contributions}

MN is Ph.D and she designed the study, performed the experiments, interpreted the data, and wrote the manuscript. VM, GC, and CC are Ph.D. and carried out clonogenic and flow cytometry assays and participated in data analyses and interpretation. RB and GM are Ph.D. and participated in data analysis and discussion and critically revised the manuscript. MC carried out microscopic observation. ER performed the statistical analysis. All authors have expertise on radiopharmacology and receptors study. VM, CC, GM and $\mathrm{RB}$ are members of the National Research Council (CONICET). MN, VM, GC,

$C C, E R, R B$, and $G M$ are professors in the University of Buenos Aires. MC is M. $D$. and he is specialist in anatomopathology. All authors read and approved the final manuscript.

\section{Acknowledgements}

This work was supported by grants from the National Agency of Scientific and Technological Promotion and from Barceló Foundation, Argentina. Vanina Medina, Claudia Cocca, Gabriela Martín and Rosa Bergoc are members of the National Research Council (CONICET).

\section{Author details}

${ }^{1}$ Radioisotopes Laboratory, School of Pharmacy and Biochemistry, University of Buenos Aires, Buenos Aires, Argentina. ${ }^{2}$ Institute of Immunooncology Dr. EJV Crescenti, Buenos Aires, Argentina. Institute of Health Sciences Barceló, Buenos Aires, Argentina.

Received: 31 March 2012 Accepted: 7 January 2013

Published: 11 January 2013

\section{References}

1. Krentz AJ, Bailey CJ: Oral antidiabetic agents. Current role in type 2 diabetes. Drugs 2005, 65:385-411.

2. Lebovitz HE: Treating hyperglycemia in type 2 diabetes: new goals and strategies. Cleve Clin J Med 2002, 69:809-820.

3. Lebovitz HE: Oral antidiabetic agents. Med Clin North Am 2004, 88:847-863.

4. Shorter K, Farjo NP, Picksley SM, Randall VA: Human hair follicles contain two forms of ATP-sensitive potassium channels, only one of which is sensitive to minoxidil. FASEB J 2008, 22:1725-1736.

5. Groop LC: Sulphonylureas in NIDDM. Diabetes Care 1992, 15:737-754.

6. Kim JA, Kang YS, Lee SH, Lee EH, Yoo BH, Lee YS: Glibenclamide induces apoptosis through inhibition of cystic fibrosis transmembrane conductance regulator (CFTR) $\mathrm{Cl}(-)$ channels and intracellular $\mathrm{Ca}(2+)$ release in HepG2 human hepatoblastoma cells. Biochem Biophys Res Commun 1999, 261:682-688.

7. Qian X, Li J, Ding J, Wang Z, Duan L, Hu G: Glibenclamide exerts an antitumor activity through reactive oxygen species-c-jun $\mathrm{NH} 2$-terminal kinase pathway in human gastric cancer cell line MGC-803. Biochem Pharmacol 2008, 76:1705-1715.

8. Wonderlin WF, Strobl JS: Potassium channels, proliferation and G1 progression. J Membr Biol 1996, 154:91-107.

9. Pardo LA: Voltage-gated potassium channels in cell proliferation. Physiology 2004, 19:285-292.

10. Parkin DM, Bray F, Ferlay J, Pisani P: Global cancer statistics, 2002. CA Cancer J Clin 2005, 55:74-108

11. Al-Dhaheri MH, Shah YM, Basrur V, Pind S, Rowan BG: Identification of novel proteins induced by estradiol, 4-hydroxytamoxifen and acolbifene in T47D breast cancer cells. Steroid 2006, 71:966-978.

12. Benson JR, Jatoi I, Keisch M, Esteva FJ, Makris A, Jordan VC: Early breast cancer. Lancet 2009, 373:1463-1479.

13. Utsumi $\mathrm{T}$, Kobayashi $\mathrm{N}$, Hanada $\mathrm{H}$ : Recent perspectives of endocrine therapy for breast cancer. Breast Cancer 2007, 14:194-199.

14. Jordan VC, Brodie AM: Development and evolution of therapies targeted to the estrogen receptor for the treatment and prevention of breast cancer. Steroids 2007, 72:7-25.

15. Park BJ, Whichard ZL, Corey SJ: Dasatinib synergizes with both cytotoxic and signal transduction inhibitors in heterogeneous breast cancer cell lines-lessons for design of combination targeted therapy. Cancer Lett 2012, 320:104-110.

16. Smith $L$, Watson MB, O'Kane SL, Drew PJ, Lind MJ, Cawkwell L: The analysis of doxorubicin resistance in human breast cancer cells using antibody microarrays. Mol Cancer Ther 2006, 5:2115-2120.

17. Joensuu H, Gligorov J: Adjuvant treatments for triple-negative breast cancers. Ann Oncol 2012, 23:vi40-vi45.

18. Soto-Cerrato V, Llagostera E, Montaner B, Scheffer GL, Perez-Tomas R: Mitochondria-mediated apoptosis operating irrespective of multidrug resistance in breast cancer cells by the anticancer agent prodigiosin. Biochem Pharmacol 2004, 68:1345-1352.

19. Mody M, Dharker N, Bloomston M, Wang PS, Chou FS, Glickman TS, McCaffrey T, Yang Z, Pumfery A, Lee D, Ringel MD, Pinzone JJ: Rosiglitazone sensitizes MDA-MB-231 breast cancer cells to anti-tumour effects of tumour necrosis factor-alpha, $\mathrm{CH} 11$ and $\mathrm{CYC} 202$. Endocr Relat Cancer 2007, 14:305-315

20. Jovanović S, Du Q, Mukhopadhyay S, Swingler R, Buckley R, McEachen J, Jovanović A: A patient suffering from hypokalemic periodic paralysis is deficient in skeletal muscle ATP-sensitive K channels. Clin Transl Sci 2008 $1: 71-74$

21. Bradford MM: A rapid and sensitive method for the quantification of microgram quantities of protein utilizing the principle of protein-dye binding. Anal Biochem 1976, 72:248-254.

22. Dimri GP, Lee X, Basile G, Acosta M, Scott G, Roskelley C, Medrano EE, Linskens M, Rubelj I, Pereira-Smith O, et al: A biomarker that identifies senescent human cells in culture and in aging skin in vivo. Proc Nat Acad Sci USA 1995, 92:9363-9367.

23. Greespan P, Mayer E, Fowler S: Nile Red: A selective fluorescent stain for intracellular lipid droplets. J Cell Biol 1985, 100:965-973.

24. Zhang GJ, Kimijima I, Onda M, Kanno M, Sato H, Watanabe T, Tsuchiya A, Abe R, Takenoshita S: Tamoxifen-induced apoptosis in breast cancer cells relates to down-regulation of bcl-2, but not bax and $\mathrm{bcl}-\mathrm{x}_{(\mathrm{L})}$, without alteration of $\mathrm{p} 53$ protein levels. Clin Cancer Res 1999, 5:2971-2977.

25. Mohamad N, Gutiérrez A, Núñez M, Cocca C, Martín G, Cricco G, Medina V, Rivera E, Bergoc R: Mitochondrial apoptotic pathways. Biocell 2005, 29:149-161

26. Schmitt E, Paquet $C$, Beauchemin M, Bertrand R: DNA-damage response network at the crossroads of cell-cycle checkpoints, cellular senescence and apoptosis. J Zhejiang Univ Sci B 2007, 8:377-397.

27. Davis T, Kennedy C, Chiew YE, Clarke CL, De Fazio A: Histone deacetylase inhibitors decrease proliferation and modulate cell cycle gene expression in normal mammary epithelial cells. Clin Cancer Res 2000 6:4334-4342.

28. Felipe A, Vicente R, Villalonga N, Roura-Ferrer M, Martínez-Mármol R, Solé L, Ferreres JC, Condom E: Potassium channels: new targets in cancer therapy. Cancer Detect Prev 2006, 30:375-385. 
29. Martin G, Melito G, Rivera E, Levin E, Davio C, Cricco G, Andrade N, Caro R, Bergoc R: Effect of tamoxifen on intraperitoneal N-nitroso-N-methylurea induced tumors. Cancer Lett 1996, 100:227-234.

30. Martin G, Rivera ES, Daivo C, Cricco G, Levin E, Cocca C, Andrade N, Caro R, Bergoc RM: Receptors characterization of intraperitoneally $\mathrm{N}$ nitroso-N-methylurea-induced mammary tumors in rats. Cancer Lett 1996, 101:1-8.

31. Cocca C, Martín G, Núñez M, Gutiérrez A, Cricco G, Mohamad N, Medina V, Croci M, Crescenti E, Rivera E, Bergoc R: Effect of glibenclamide on Nnitroso-methylurea-induced mammary tumors in diabetic and nondiabetic rats. Oncology Res 2005, 15:301-311.

32. Bodenstine TM, Vaidya KS, Ismail A, Beck BH, Diers AR, Edmonds MD Kirsammer GT, Landar A, Welch DR: Subsets of ATP-sensitive potassium channel (KATP) inhibitors increase gap junctional intercellular communication in metastatic cancer cell lines independent of SUR expression. FEBS Lett 2012, 586:27-31.

33. Du Q, Jovanović S, Sukhodub A, Barratt E, Drew E, Whalley KM, Kay V, McLaughlin M, Telfer EE, Barratt CL, Jovanović A: Human oocytes express ATP-sensitive $\mathrm{K}(+)$ channels. Hum Reprod 2010, 25:2774-2782.

34. Ouadid-Ahidouch $\mathrm{H}$, Ahidouch $\mathrm{A}: \mathrm{K}+$ channel expression in human breast cancer cells: involvement in cell cycle regulation and carcinogenesis. J Membr Biol 2008, 221:1-6.

35. Jang SS, Park J, Hur SW, Hong YH, Hur J, Chae JH, Kim SK, Kim J, Kim HS, Kim SJ: Endothelial progenitor cells functionally express inward rectifier potassium channels. Am J Physiol Cell Physiol 2011, 301:C150-C161.

36. Woodfork KA, Wonderlin WF, Peterson VA, Strobl JS: Inhibition of ATPsensitive potassium channels causes reversible cell-cycle arrest of human breast cancer cells in tissue culture. J Cell Physiol 1995, 162:163-171.

37. Malhi H, Irani AN, Rajvanshi P, Suadicani SO, Spray DC, McDonald TV, Gupta S: KATP channels regulate mitogenically induced proliferation in primary rat hepatocytes and human liver cell lines. Implications for liver growth control and potential therapeutic targeting. J Biol Chem 2000, 275:26050-26057.

38. Abdul M, Santo A, Hoosein N: Activity of potassium channel-blockers in breast cancer. Anticancer Res 2003, 23:3347-3351.

39. Huang W, Acosta-Martínez M, Levine JE: Ovarian steroids stimulate adenosine triphosphate-sensitive potassium (KATP) channel subunit gene expression and confer responsiveness of the gonadotropinreleasing hormone pulse generator to KATP channel modulation. Endocrinology 2008, 149:2423-2432.

40. Diehl JA: Cycling to cancer with cyclin D1. Cancer Biol Ther 2002, 1:226-231.

41. Gladden AB, Diehl JA: Location, location, location: the role of cyclin D1 nuclear localization in cancer. J Cell Biochem 2005, 96:906-913.

42. Möröy T, Geisen C: Cyclin E. Int J Biochem Cell Biol 2004, 36:1424-1439.

43. Conradie R, Bruggeman FJ, Ciliberto A, Csikász-Nagy A, Novák B, Westerhoff $H V$, Snoep JL: Restriction point control of the mammalian cell cycle via the cyclin E/Cdk2:p27 complex. FEBS J 2010, 277:357-367.

44. Eto I: Upstream molecular signaling pathways of p27(Kip1) expression in human breast cancer cells in vitro: differential effects of 4hydroxytamoxifen and deficiency of either D-(+)-glucose or L-leucine. Cancer Cell Int. 2011, 11:31.

45. Christov K, Grubbs CJ, Shilkaitis A, Juliana MM, Lubet RA: Short-term modulation of cell proliferation and apoptosis and preventive/ therapeutic efficacy of various agents in a mammary cancer model. Clin Cancer Res 2007, 13:5488-5496.

46. Iwakura T, Fujimoto S, Kagimoto S, Inada A, Kubota A, Someya Y, Ihara Y, Yamada $Y$, Seino $Y$ : Sustained enhancement of $\mathrm{Ca}(2+)$ influx by glibenclamide induces apoptosis in RINm5F cells. Biochem Biophys Res Commun 2000, 271:422-428.

47. You H, Yu W, Sanders BG, Kline K: RRR-a-tocopheryl succinate induces MDA-MB-435 and MCF-7 human breast cancer cells to undergo differentiation. Cell Growth Diff 2001, 12:471-480.

48. Münster PN, Srethapakdi M, Moasser MM, Rosen N: Inhibition of heat shock protein 90 function by ansamycins causes the morphological and functional differentiation of breast cancer cells. Cancer Res 2001, 61:2945-2952

49. Fattman $\mathrm{CL}$, An B, Sussman L, Dou QP: p53-independent dephosphorylation and cleavage of retinoblastoma protein during tamoxifen-induced apoptosis in human breast carcinoma cells. Cancer Lett 1998, 130:103-113.
50. Ferlini C, Scambia G, Marone M, Distefano M, Gaggini C, Ferrandina G, Fattorossi A, Isola G, Benedetti Panici P, Mancuso S: Tamoxifen induces oxidative stress and apoptosis in oestrogen receptor-negative human cancer cell lines. Br J Cancer 1999, 79:257-263.

51. Mandlekar S, Yu R, Tan TH, Kong AN: Activation of caspase-3 and c-Jun $\mathrm{NH} 2$-terminal kinase-1 signaling pathways in tamoxifen-induced apoptosis of human breast cancer cells. Cancer Res 2000, 60:5995-6000.

52. Scandlyn MJ, Stuart EC, Somers-Edgar TJ, Menzies AR, Rosengren RJ: A new role for tamoxifen in oestrogen receptor-negative breast cancer when it is combined with epigallocatechin gallate. Br J Cancer 2008, 99:1056-1063.

53. Zhang $X$, Ding L, Kang L, Wang ZY: Estrogen receptor-alpha 36 mediates mitogenic antiestrogen signaling in ER-negative breast cancer cells. PLOS One 2012, 7:e30174.

54. Chen JH, Ling R, Yao Q, Li Y, Chen T, Wang Z, Li KZ: Effect of small-sized liposomal Adriamycin administered by various routes on a metastatic breast cancer model. Endocr Relat Cancer 2005, 12:93-100.

55. Payen L, Delugin L, Courtois A, Trinquart Y, Guillouzo A, Fardel O: The sulphonylurea glibenclamide inhibits multidrug resistance protein (MRP1) activity in human lung cancer cells. Br J Pharmacol 2001, 132(3):778-784.

56. Lee I, Park C, Kang WK: Knockdown of inwardly rectifying potassium channel Kir2.2 suppresses tumorigenesis by inducing reactive oxygen speciesmediated cellular senescence. Mol Cancer Ther 2010, 9(11):2951-2959.

doi:10.1186/2050-6511-14-6

Cite this article as: Núñez et al:: Glibenclamide inhibits cell growth by inducing G0/G1 arrest in the human breast cancer cell line MDA-MB231. BMC Pharmacology and Toxicology 2013 14:6.

\section{Submit your next manuscript to BioMed Central and take full advantage of:}

- Convenient online submission

- Thorough peer review

- No space constraints or color figure charges

- Immediate publication on acceptance

- Inclusion in PubMed, CAS, Scopus and Google Scholar

- Research which is freely available for redistribution

Submit your manuscript at www.biomedcentral.com/submit
C) Biomed Central 